\title{
ZDRAVSTVENA NEGA OBOLELIH OD KARCINOMA DOJKE SA METASTATSKIM PROMENAMA NA ENDOKRANIJUMU
}

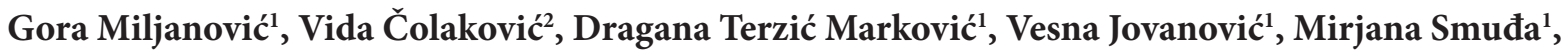 \\ Biljana Jakovljević ${ }^{1}$
}

1. Akademija strukovnih studija Beograd, Odsek Visoka zdravstvena škola, Beograd

2. Institut za onkologiju i radiologiju Srbije, Beograd

Autor za korespodenciju:

\section{Vida Čolaković}

Institut za onkologiju i radiologiju Srbije

Pasterova 14, 11000 Beograd, Republika Srbija

tel:+381 649217310

e-mail: colakovic.vida93@yahoo.com

\author{
Proces prihvatanja/Article history: \\ Primljen/Received 11.08.2021. \\ Revidiran/Received in revised form \\ 19.09.2021. \\ Prihvaćen/Accepted 29.09.2021.
}

\section{SAŽETAK}

Uvod: Karcinom dojke predstavlja promenu zdravih ćelija dojke u maligne ćelije. Bolest se može odlikovati metastazama koje mogu biti u rasponu od ograničenih koštanih metastaza do široko rasprostranjenih i opasnih po život. Osnovni cilj lečenja i zdravstvene nege je ublažavanje simptoma, uspešna kontrola bolesti i očuvanje kvaliteta života uz što duže preživljavanje.

Cilj: Prikazati specifičnosti u zdravstvenoj nezi pacijentkinje obolele od karcinoma dojke sa metastatskim promenama na endokranijumu.

Metode rada: U radu su korišćene deskriptivna metoda i opservaciona direktna metoda-studija slučaja: Prikaz pacijentkinje sa karcinomom dojke i metastatskim promenama na mozgu po metodi Procesa zdravstvene nege (PZN).

Diskusija: Savremena zdravstvena nega zagovara negu pacijenta po naučno zasnovanoj metodi, univerzalnoj u sestrinskoj praksi PZN, po kome je nega usredsređena na pacijenta/porodicu uvažavajući njihove preferencije. PZN uključuje: kontinuiranu procenu stanja pacijenta i definisanje problema i potreba za negom, postavljanje ciljeva i odabir optimalnih strategija zbrinjavanja. Najčešći kolaborativni problemi kod naše pacijentkinje su bili: bol, umor, anemija, insomnija. Problemi koje su sestre rešavale kroz samostalne intervencije su bili: deficit u samozbrinjavanju, prevencija padova i povreda, deficit znanja u vezi sa procedurom zračenja, rizik za infekciju, i mogućnost nastanka viška volumena tečnosti.

Zaključak: Pacijentkinje sa uznapredovalim karcinomom dojke i njihove porodice imaju složene potrebe, čije nezadovoljenje može rezultirati narušavanjem kvaliteta života, te je neophodan individualni pristup u proceni stanja pacijenta, utvrđivanju potreba, i planiranja intervencija koje su zasnovane na naučnim dokazima, raspoloživim zdravstvenim resursima i preferencijama pacijenata/porodice. Nega pacijenta po metodi PZN, obećava celovitiji pristup, poboljšano iskustvo pacijenta kao i poboljšane medicinske ishode.

Ključne reči: rak dojke, metastaze na mozgu, sestrinske intervencije, proces zdravstvene nege

\section{ABSTRACT}

Introduction: Breast cancer is the transformation of healthy breast cells into malignant cells. The disease is characterized by metastases that can range from limited bone metastases to widespread and life-threatening metastases. The main goal of caring for these patients is to successfully control the symptoms of the disease, the side effects of the tumor while preserving the quality of life and surviving as long as possible.

Objective was to show the specifics of interventions in the health care of a patient with breast cancer with metastatic changes in the endocranium

Methods: We used a descriptive method and a conservative direct method: case study of a patient with breast cancer and metastatic changes in the brain according to the method of the Nursing Care Process (NCP).

Discussion: Modern nursing care implies patient care according to a scientifically based method, universal in the nursing practice $\mathrm{NCP}$, according to which care is focused on the patient/family, respecting their preferences. NCP includes: continuous assessment of the patient's condition and defining problems and care needs, setting goals and selecting optimal care strategies. The most common collaborative problems for our patient were: pain, fatigue, anemia, insomnia. The problems that the nurses solved through independent interventions were: deficit in self-care, prevention of falls and injuries, lack of knowledge regarding the radiation procedure, risk of infection, and the possibility of excess fluid volume.

Conclusion: Patients with advanced breast cancer and their families have complex needs, the failure of which can result in impaired quality of life. An individual approach is needed in assessing the patient's condition, identifying needs, and planning interventions based on scientific evidence, available health resources, and preferences of patient/family. Patient care according to the NCP method promises a more comprehensive approach, improved patient experience as well as improved medical outcomes.

Key words: breast cancer, brain metastases, nursing interventions, nursing care process 


\section{UVOD}

Tumori predstavljaju heterogenu grupu bolesti uglavnom poznate etiologije, mada su i dalje mnogi etiološki činioci nepoznati. Karcinogeni ili kancerogeni predstavljaju štetne faktore ili agense koji izazivaju pojavu tumora, neoplazmi ili kancera u organizmu [1]. Rak dojke je najčešći rak kod žena i vodeći je uzrok smrti povezane sa rakom kod žena u regionima u razvoju i razvijenim regionima. Uvidom u literature oko $5 \%-10 \%$ novodijagnostikovanih pacijenata sa rakom dojke je metastatski u trenutku dijagnoze; od toga će približno jedna petina preživeti 5 godina. Među pacijentima kojima je dijagnostikovana rana faza bolesti, u zavisnosti od faktora rizika, čak 30\% negativnih lokalnih promena i do $70 \%$ karcinoma dojke sa pozitivnim lokalnim promenama razviće metastatsku bolest [2,3.] Karcinom dojke u Srbiji ima izuzetno veliki značaj zbog nekoliko karakteristika: najčešći je maligni tumor kod žena, vodeći je uzrok smrti među malignim tumorima, ima stalan porast incidence i mortaliteta, otkriva se najčešće u odmaklom stadijumu bolesti i odsustvo i/ili nedosledna primena obaveznih skrining programa [4].

Metastatski karcinom dojke javlja se kada ćelije iz primarnog tumora dojke metastaziraju u druge delove tela kroz krvni ili limfni sistem. Bolest može biti u rasponu od ograničenih koštanih metastaza do široko rasprostranjenih i opasnih po život metastaza u visceralnim organima kao što su jetra, pluća i mozak. Metastatski karcinom dojke je neizlečiv, a osnovni cilj lečenja je palijativna kontrola tj. ublažavanje simptoma, stabilizovanje komplikacija tumora, uz očuvanje kvaliteta života i poboljšanje celokupnog preživljavanja [5]. Metastaze u mozgu mogu biti asimptomatske i prilično često pacijenti nemaju tegobe. Međutim, većina moždanih metastaza dijagnostikuje se na osnovu neuroloških simptoma [6]. Cerebralne metastaze su najčešće intrakranijalne neoplazme u odraslih, a najčešće intrakranijalno mesto metastaze je upravo moždani parenhim. Simptomi se razlikuju zavisno od lokalizacije lezije. Pareze i paralize, fokalni neurološki deficit, senzorni i motorni ispadi, kranijalne neuropatije, samo su neke od manifestacija prisustva cerebralnih metastaza [7]. Vrste simptoma koji se mogu javiti kod metastaza u mozgu su:

Fizički simptomi - glavobolja, napadi, mučnina, slabost mišića, problemi sa vidom i problemi sa crevima i bešikom.
Kognitivni simptomi - promene ličnosti, konfuzija, oslabljena procena, gubitak pamćenja i socijalno neprikladno ponašanje.

Emocionalni simptomi - depresija, anksioznost, bes i druge emocionalne promene.

Lečenje- početna nefarmakološka terapija metastaza u mozgu uključuje lokalno usmerenu terapiju hirurškom resekcijom, radiohirurgiju i terapiju zračenjem celog mozga [8]. Ako je broj metastaza u mozgu mali i ograničen, često se primenjuje samo lokalna terapija kao što je npr. radioterapija ili operacija gama nožem. Ako pacijenti primaju sistemsku terapiju i njihova sistemska bolest je, u velikoj meri, pod kontrolom, ali su imali male promene u mozgu često se nastavlja ta sistemska terapija i lokalno leče metastaze dok god su pod kontrolom. Budući da su mnoge toksičnosti povezane sa zračenjem čitavog mozga, ono je rezervisano za pacijente koji imaju veliku količinu metastaza u mozgu, novi tumor ili metastaze većih dimenzija kao što je slučaj u našem istraživanju, kod pacijentkinje u prikazanom slučaju.

Pacijenti mogu imati velike poteškoće usled težine bolesti ili tretmana koji primaju, kao što je radioterapija celog mozga, usled akutnih i kasnijih efekata toksičnosti celog mozga. Radioterapija može uticati na pamćenje pacijenata, koji mogu postati sve zaboravniji, što može otežati lečenje i stvoriti porodici opterećenje za adekvatnu brigu o pacijentu. Depresija, anksioznost i pad kvaliteta života javljaju se kod pacijenata sa metastazama u mozgu a postoji rizik od venske tromboze i tromboembolije [6]. Budući da se tretman lečenja i zdravstvene nege žena sa metastatskim rakom dojke često produžava, prevalencija metastatskih bolesti je velika i zaista je briga o ženama sa metastatskim rakom dojke glavni izazov za onkologe i timove za palijativno zbrinjavanje [2]. Rak dojke karakterišu mnoge fizičke manifestacije sa potencijalom da naruše kvalitet života (najviše povezane sa rakom, a neke i sa lečenjem), kao i značajnim uticajem na psihosocijalno blagostanje $[3,9]$. Pacijentima u terminalnoj fazi sa karcinomom dojke kao i sa drugim onkološkim bolestima potrebna je posebna nega, a članovima njihovih porodica podrška. Pacijenti ne samo da trpe bolove i velike psihičke traume, već su i članovi porodica izloženi velikom psihičkom i finansijskom pritisku, naročito u zemljama u razvoju usled čestog izostajanja socijalne podrške [10]. Uzimajući u obzir kompletnu raznolikost faktora koji mogu doprineti nelagodnosti pacijenta, naglašava se potreba za metodskim pristupom pro- 
ceni svakog pojedinačnog slučaja [11].

Procena pacijenta; Rano uspostavljanje dobre kontrole simptoma redukuje zabrinutost, gradi poverenje pacijenata i njihovih porodica i olakšava sposobnost rešavanja drugih važnih pitanja.Varijable pacijenta koje se moraju proceniti uključuju status bolesti, očekivano napredovanje bolesti, sadašnji funkcionalni nivo, simptome, trenutne terapije i očekivane buduće probleme. Od posebne važnosti je nivo funkcionalnosti pacijenta, koji odražava: nivo budnosti, stepen pokretljivosti, sposobnost komunikacije, sposobnost obavljanja svakodnevnih aktivnosti, funkciju creva i bešike. Korišćenje potvrđenih instrumenata u sestrinskoj praksi po metodi Procesa zdravstvene nege za procenu bolova i simptoma može pružiti format za komunikaciju između pacijenata i sestre kao i ostalih zdravstvenih radnika, a ovi instrumenti se takođe mogu koristiti za praćenje adekvatnosti terapije i uspešnu kontrolu simptoma. Važno je utvrditi razumevanje pacijenata i njihovih porodica o prirodi i obimu bolesti i njihovim očekivanjima od lečenja $i$ ishoda.

Procena porodice obuhvata medicinske promenljive, psihosocijalne probleme i adekvatnost i dostupnost podrške. Potrebno je proceniti istovremene medicinske probleme članova porodice, posebno primarnog negovatelja, jer održivost plana kućne nege može zavisiti od sposobnosti članova porodice da učestvuju u nezi. Budući da je sposobnost porodica da se nose sa kućnom negom u velikoj meri određena prirodom dostupnih pomoćnih sredstava za kućnu negu, porodična procena mora uključivati procenu dostupne zdravstvene zaštite i podrške zajednice. Deficiti znanja možda su se namerno održavali: porodica ili pacijent koji ne žele preopterećenost informacijama, pacijent koji štiti porodicu od saznanja o lošoj prognozi ili porodica koja štiti pacijenta od uticaja takvih informacija [12].

Cilj ovog rada je da se prikažu specifičnosti u zdravstvenoj nezi pacijentkinje obolele od karcinoma dojke sa metastatskim promenama na endokranijumu.

Istraživanje je sprovedeno na Institutu za onkologiju i radiologiju Srbije (IORS), u septembru 2020. Godine, nakon dobijanja pismenog odobrenja Etičkog odbora IORS za sprovođenje istraživanja. U radu će biti prikazano stanje pacijentkinje praćeno kroz Proces zdravstvene nege tokom 24 sata.

U radu su korišćene deskriptivna metoda i opservaciona direktna metoda-studija slučaja: Prikaz pacijentkinje obolele od karcinoma dojke sa metastatskim promenama na endokranijumu. Tehnike istraživanja su podrazumevale: posmatranje, procenu i opisivanje stanja i potreba za negom, analizu medicinske dokumentacije i vođenje dokumentacije Procesa zdravstvene nege kreirane za potrebe izvođenja vežbi studenata Akademije strukovnih studija Beograd, Odseka Visoke zdravstvene škole.

\section{PRIKAZ SLUČAJA PO PROCESU ZDRAVSTVENE NEGE}

Sestrinska opservacija - opšti podaci i utisci o pacijentu

Pacijentkinja NN (48 godina) profesor fizike u penziji, živi u prigradskom naselju kod Beograda, u porodičnoj kući sa suprugom. Imaju jednu kćerku - sa kojom imaju skladan odnos, udata je i često ih posećuje. Bila je hospitalizovana na onkološkom odeljenju, nekoliko puta u poslednje dve godine. Druga oboljenja ne navodi, kao ni operacije, takođe ni alergiju na hranu i lekove. Bolest je dijagnostikovana u četvrtom kliničkom stadijumu kao lokalno uznapredovali karcinom dojke uz prisustvo aksilarne limfadenopatije. Lečenje je započeto primenom sistemske hemioterapije, sa efektom progresije uz pojavu metastatskih promena na endokranijumu i jetri. Dalje lečenje nastavlja primenom zračne terapije metastatskih promena na endokranijumu. Na osnovu procene stanja, fizikalnog pregleda, analize dokumentacije i razgovora sa pacijentkinjom definisani su i sledeći problemi: bol, vrtoglavica, zavisnost u obavljanju aktivnosti svakodnevnog života, nametnuta restrikcija u kretanju, osećaj umora i otežano uspavljivanje, plasirana intravenska kanila, plasiran stalni urinarni kateter.

Procena zdravstvenog stanja: Orijentisana u prostoru i vremenu, prema sebi i drugima. Urednih vitalnih parametara: TA 115/70mmHg, disanje bez problema, ne kašlje, broj respiracija $17 / \mathrm{min}$, puls dobro punjen $70 / \mathrm{min}$, afebrilna $\mathrm{T} 36.3^{\circ} \mathrm{C}$. Koža i vidljive sluzokože bez promena, normalne prebojenosti. Apetit je dobar, telesna masa $55 \mathrm{~kg}$ i visina $167 \mathrm{~cm}$. Očuvane senzorne funkcije, komunikacija je uredna, koristi naočare za vid.

Procena funkcionalnog stanja: Od tegoba navodi vrtoglavicu i glavobolju koja je povremeno jakog inteziteta, sa širenjem bola ka vratu i ramenom pojasu, pojačava se prilikom vertikalizacije. Ne kreće se samostalno, nametnuta restrikcija u kretanju u cilju prevencije pada. Položaj u postelji zauzima samostal- 
no. Aktivnosti svakodnevnog života obavlja uz pomoć, odnosno obavljanje lične higijene i fizioloških potreba u postelji, kao i oblačenje i presvlačenje. Ima plasiran stalni urinarni kateter Folly No 18, urin normalne boje i količine. Na drugi dan ima formiranu stolicu. Ima problem sa uspavljivanjem zbog bolova i promene ambijenta, ondnosno hospitalizacije, i potrebu za uzimanjem sedativa. Navodi i subjektivni osećaj umora. Ima plasiranu intravensku kanilu u levoj ruci na unutrašnjoj strani podlaktice. Regija mesta plasirane kanile bez znakova infekcije. Bez prisustva edema i na ostalim ekstremitetima. Nije pušač, ne konzumira alkohol i želi više da se informiše o terapijskom tretmanu i efektima zračne terapije.

\section{PLAN ZDRAVSTVENE NEGE}

\section{Dolor}

Cilj nege:

1. Pacijentkinja će za sat vremena verbalizovati da bol popušta u intezitetu

1.a. Pacijentkinja će imati bol inteziteta na skali ispod četiri, za šest sati

Planirane intervencije:

- Procena subjektivnog doživljava intenziteta bola numeričkom skalom

- Kontrola bola numeričkom skalom nakon primene ordinirane terapije

- Primena nefarmakoloških i farmakoloških strategija za smanjenje ili otklanjanje bola

- Primena ordinirane terapije po nalogu lekara (Oramorph kapi 4gtt/4h per os i po potrebi u proboju bola, transdermalni flaster Durogesic $25 \mathrm{mcg} / 72 \mathrm{~h}$ )

\section{Umor}

Cilj nege:

2. Racionalno će trošiti energiju i odmoriti se kada oseti umor prilikom obavljanja aktivnosti dnevnog života do kraja hospitalizacije

Planirane intervencije:

- Adekvatna procena i kontrola umora

- Adekvatno planiranje aktivnosti dnevnog života u skladu sa osećajem nivoa umora

- Adekvatna primena farmakoloških intervencija po nalogu (lečenje anemije, poremećaja spavanja)

- Adekvatno planiranje i kontrola nefarmakoloških intervencija po želji razgovor, dodatne posete porodice i prijatelja, film, opuštajuća literature

\section{Anemia}

Cilj nege:

3. Uskladiti ishranu i odmor do kraja hospitalizacije

3.a.Vrednosti hemoglobina i eritrocita biće $u$ granicama referentnih vrednosti do kraja hospitalizacije

Planirane intervencije:

- Adekvatan izbor i planiranje nefarmakoloških strategija za obnavljanje energije (aktivnosti, ishrana, fizičke vezbe, opuštanje)

- U dogovoru sa nutricionistom uskladiti ishranu bogatu belančevinama i gvožđem

- Pomoć pri ishrani

- Ordinirana terapija po nalogu

- Uzimanje biološkog materijala po nalogu, za

labotatorijske analize krvi za kontrolu krvne slike i biohemije i dr.

4. Smetnje sa snom u vezi sa prisutnim bolovima $i$ hospitalizacijoma manifestuje se težim uspavljivanjem i budjenjem u toku noći

Cilj nege:

4. Pacijentkinja će spavati u kontinuitetu četiri sata, a tokom 24 sata ukupno osam sati

4.a. Održati postignuti kontinuitet sna za tri dana Planirane intervencije:

- Omogućiti udoban i miran ambijent tokom noći

- Primena ordinirane terapije po nalogu lekara, tbl Bensedin $5 \mathrm{mg}$ per os u $21 \mathrm{~h}$

5. Deficit u samozbrinjavanju u vezi sa ograničenim kretanjem i mogućnošću povređivanja-obavljanje lične higijene, obavljanje fizioloških potreba, presvlačenje $i$ ishrane uz pomoć

Cilj nege:

5. Obezbediti pomoć tokom obavljanja fizioloških potreba i aktivnosti samozbrinjavanja u postelji do kraja hospitalizacije

Planirane intervencije:

- Uspostaviti odnos poverenja i osloboditi pacijentkinju, da pozove kad joj je potrebna pomoć

- Održavanje higijene kože i vidljivih sluzokoža pacijentkinje u postelji dva puta dnevno i po potrebi (umivanje, prenje ruku, kupanje uz pomoć)

- Toaleta anogenitalne regije dva puta dnevno i nakon svake defekacije, postavljanje pelene ili 
noćne posude po potrebi

- Pomoć pri presvlačenju ličnog rublja, promena posteljnog rublja jednom dnevno i po potrebi - Vertikalizacija 3 puta po deset minuta u toku dana, vežbe disanja tri puta dnevno po 10 respiracija, pasivne vežbe u postelji dva puta dnevno.

6. Deficit znanja u vezi sa predstojećim terapijskim tretmanom manifestuje se željom da se informiše o terapiji zračenjem i dužini hospitalizacije

Cilj nege:

6. Biće informisana o predstojećem radioterapijskom tretmanu za dva dana

Planirane intervencije:

- Planirati edukativni razgovor sa pacijentkinjom u popodnevnoj smeni (17h)

- Objasniti pripremu za zračnu terapiju, odnosno obeležavanje zračnog polja na simulatoru

- Objasniti značaj postavljanja termoplastične maske i saradnje sa zdravstvenim radnicima

- Ohrabriti pacijentkinju i uliti joj poverenje u znanje i stručnost zdravstvenih radnika

\section{Mogućnost nastanka povećanja volumena tečno-} sti u mozgu u vezi sa zračnim tretmanom

Cilj nege:

7. Neće doći do povećanja volumena tečnosti u mozgu do kraja radioterapijskog tretmana

Planirane intervencije:

- Praćenje stanja svesti,

- Praćenje i evidentiranje pojave mučnine, povraćanja,

- Praćenje i evidentiranje pojave i karakteristika epi napada

- Primena ordinirane terapije po nalogu, antiedematozne (sol 20\% Manitol 125ml/12h i.v., amp Dexason $4 \mathrm{mg}$ i.v., uz gastroprotekciju tbl Nolpaza 20mg)

- Kontrola vitalnih parametara tokom 24 časa

(TA i P na šest sati, T na 12 sati)

- Praćenje bilansa tečnosti

\section{Mogućnost pada i povređivanja u vezi sa vrto-} glavicom

Cilj nege:

8. Neće doći do pada i povređivanja do kraja hospitalizacije
Planirane intervencije:

- Permanentan nadzor

- Postavljanje zaštitnih ogradica na krevet

- Praćenje i otklanjanje provocirajućih faktora pada

- Obezbediti mir i relaksirajući položaj u postelji

9. Mogućnost nastanka infekcije mokraćnih puteva $u$ vezi sa plasiranim urinarnim kateterom

Cilj nege:

9. Neće doći do infekcije mokraćnih puteva do kraja hospitalizacije

Planirane intervencije:

- Dezinfekcija urinarnog katetera i oreficijuma

3 puta dnevno i nakon svake defekacije sa sol

Octanisept

- Promena uro-kesa 2 puta dnevno i češće po potrebi

- Praćenje izgleda i količine izlučenog urina

- Promena urinarnog katetera na 14 dana i češće

- Uzimanje uzorka urina za urinokulturu, po nalogu lekara

10. Mogućnost upale vene u vezi sa plasiranom intravenskom kanilom

\section{0.a Mogućnost ekstravazacije intravenskih} rastvora i lekova

Cilj nege:

10. Neće doći do infekcije venskog puta do kraja hospitalizacije

10a. Neće doći do ekstravazacije intravenskih rastvora i lekova do kraja hospitalizacije

Planirane intervencije:

- Procena izgleda i stanja ubodnog mesta i okolnog tkiva

- Dezinfekcija ubodnog mesta jednom dnevno, zamena flastera jednom dnevno

- Aspiracija sadržaja iz intravenske kanile pre primene terapije

- Održavanje prohodnosti intravenske kanile nakon primene terapije: koristeći do $5 \mathrm{ml}$ sol 0,9\% $\mathrm{NaCl}$

- Zamena intravenske kanile na 72 sata i po potrebi ranije 


\section{Mogućnost nastanka oštećenja integriteta kože u vezi sa ograničenom pokretljivošću u postelji}

Cilj nege:

11. Neće doći do oštećenja integriteta kože do

kraja hospitalizacije

Planirane intervencije:

- Pomoć pacijentkinji u održavanju lične higijene

- u jutarnjim i večernjim satima

- Promena posteljnog i ličnog rublja više puta u toku dana, prema potrebi

- Inspekcija kože i vidljivih sluzokoža tri puta dnevno

- Stimulisati pacijentkinju za aktivnu promenu položaja u postelji, na dva sata i češće

- Objasniti značaj promene položaja u postelji na dva sata i češće

Evaluacija postignutih ciljeva u okviru 24-o časovnog praćenja pacijentkinje:

Cilj 1. ostvaren - primenom ordinirane antidolorozne i antiedematozne terapije bolovi nakon jednog sata su manjeg inteziteta (na skali od 1-10, pacijentkinja ocenjuje nivo inteziteta bolova brojem 6), cilj 1.a. ostvaren - nakon šest sati pacijentkinja ocenjuje kao nivo inteziteta bola brojem 3 .

Cilj 4. ostvaren - pacijentkinja spavala u kontinuitetu četiri sata, ukupno za 24 sata osam sati sna.

Cilj 6. ostvaren - nakon obavljenog razgovora pacijentkinja se subjektivno bolje oseća, smanjen je osećaj umora i iscrpljenosti, vidno raspoložena.

U skladu sa stanjem pacijentkinje sprovođenje aktivnosti samozbrinjavanja uz pomoć, u kontinuitetu. Pacijentkinja izvodi sve zadate vežbe u postelji. Bez znakova povećanja intrakranijalnog pritiska. Nametnuta restrikcija u kretanju, postavljene zaštitne ogradice na krevet. Održava se kontinuitet u eliminaciji urina, bez znakova urinarne infekcije. Intravenska kanila prohodna, bez znakova infekcije okolnog tkiva. Ne uočava se oštećenja integriteta kože i vidljivih sluznica.

\section{DISKUSIJA}

Zbrinjavanje pacijenta obolelog od raka dojke podrazumeva brigu i usluge zbrinjavanja od strane multiprofesionalnih timova koji rade u zdravstvenim ustanovama na sva tri nivoa, pri čemu je neophodna adekvatna kružna interprofesionalna saradnja u cilju pružanja blagovremene sveobuhvatne podrške paci- jentu i porodici. Medicinska sestra kao sastavni član interprofesionalnog tima ima niz specifičnih zadataka tokom zbrinjavanja pacijenta obolelog od raka dojke shodno standardima zdravstvene ustanove $\mathrm{u}$ kojoj radi i svojim profesionalnim kompetencijama. Adekvatno zbrinjavanje pacijenta sa metastazama na mozgu, podrazumeva; uspešnu kontrolu simptoma bolesti i neželjenih efekata tumora, uz obezbeđenje kvaliteta života i što duže preživljavanje [5].

Zdravstvena nega ovih pacijenata počinje anamnezom i analizom dokumentacije, procenom i utvrđivanjem stanja i potreba pacijenta i porodice, zajedničkim definisanjem aktuelnih i potencijalnih problema pacijenta i porodice a nastavlja se definisanjem ciljeva nege i odabirom odgovarajućih strategija za njihovu realizaciju, kao i dinamičnom evaluacijom vremenski određenih ciljeva. Ublažavanje simptoma i neželjenih efekata, važan je deo zbrinjavanja pacijenata obolelih od karcinoma, i naziva se palijativno zbrinjavanje koje se može nastaviti čak i kada prestane aktivni tretman za izlečenje ili usporavanje dijagnostikovane vrste raka.

Savremena zdravstvena nega teži primeni zdravstvene nege zasnovane na naučnim dokazima, a strategije zbrinjavanja/nege pacijenata obolelih od raka se određuju u saradnji sa pacijentom, porodicom, kao i raspoloživim zdravstvenim i porodičnim resursima kao što su; lekovi (kortikosteroidi, antikonvulzivi i analgetici), pomoćni uređaji (hodalice, invalidska kolica i dr.), emocionalna podrška poput savetovanja, rehabilitacija (govorna - jezička i fizikalna), odgovarajuće zdrave ishrane, kao i komplementarne terapije (vežbe disanja, masaža, meditacija i akupunktura, duhovna i religijska potpora).

Odmicanjem vremena nakon dijagnoze raka tokom lečenja, terapijski prozor se sužava i verovatnoća postizanja značajne koristi od terapija koje modifikuju bolesti se smanjuje sve dotle da dalja ispitivanja tretmana koji modifikuju bolest ili više nisu korisna ili imaju veću verovatnoću štete nego koristi, kada palijacija i podrška postaju centralni fokus nege.

Sve se to odražava na ciljeve nege, dok kod pacijenata sa ranim metastatskim karcinomom cilj produženja preživljavanja ponekad može imati prednost i u odnosu na udobnost. Kako bolest napreduje i verovatnoća produženja života se smanjuje, a pitanja udobnosti i funkcije imaju sve veći prioritet. U svim slučajevima sa pacijentom i njegovom porodicom treba razgovarati o prevladavajućim ciljevima nege, a sve zainteresovane strane treba da budu svesne pre- 
vladavajućih prioriteta, jer oni postavljaju kontekst za donošenje odluka i planiranje nege [13].

Uspešan odabir strategija zbrinjavanja podrazumeva adekvatnu saradnju i timski rad svih zainteresovanih strana (zdravstveni sektor ustanova interprofesionalni tim, porodica i zajednica). Da bi dobro planirala zdravstvenu negu medicinska sestra pored procene stanja pacijenta i definisanja njegovih potreba treba da proceni najbolje strategije nege zasnovane na naučnim dokazima koje bi se mogle primeniti kod konkretnog pacijenta a nakon toga mogućnosti zdravstvene ustanove i tima za negu uključujući preferencije pacijenta i porodice.

Bol kao jedan uobičajeni simptom raka dojke kod žena, povezan je sa metastazama u kostima (kičmeni prošljenovi, kuk, karlica) čije posledice, uključuju moguće prelome i kompresiju susednih neuralnih struktura $[14,15,16]$. Ostali simptomi ređeg bola uključuju tumorski bol iza zida grudnog koša, glavobolje od metastaza u mozgu kao i bolove u trbuhu usled kapsularne distenzije jetre [14].

Upravljanje bolom zahteva multidisciplinarni pristup koji uključuje zbrinjavanje koje podrazumeva sveobuhvatnu negu uz primenu antitumorske terapije (hiruška, hormonalna, hemoterapija, biološka i radioterapija), analgetičku terapiju, rehabilitaciju i psihološku negu $[15,17,18]$. Tokom procene simptoma bola neophodno je prepoznati mehanizam bola (simptomatski, neuropatski), jačina bola, trajanje, kao i manifestaciju kako bi se primenila adekvatna analgetička farmakoterapija. Opoidna analgetička terapija mora se titrirati da bi se sprovodila uz često praćenje kako adekvatnosti analgezije, tako i pojave neželjenih efekata kao što su pospanost, konfuzija, mučnina, mioklonus ili zatvor. Sestrinske intervencije u kontroli nabrojanih manifestacija bola, predstavljaju nezaobilazne procedure nadzora i doprinosa tokom zapažanja neadekvatnosti analgezije ili prekomernih neželjenih efekata, primenjenih strategija lečenja, što doprinosi pronalaženju adekvatnog i prihvatljivog balansa između pružanja olakšanja i neželjenih efekata.

Umor je jedan od najčešćih simptoma kod pacijenta sa rakom dojke [19]. Ima trenutni uticaj ako ometa pacijenta da održava normalan način života, a smatra se da ima značajne simboličke posledice u meri u kojoj sugeriše postojani morbiditet koji podseća na rizik od smrti. U mnogim slučajevima mogu postojati osnovni faktori akutni ili hronični, koji mogu ubrzati ili pogoršati umor. To može uključivati anemiju, infekciju, povišenu temperature, dehidrataciju, poremećaj ravnoteže elektrolita, kaheksiju, depresiju, poremećaj spavanja i drugo. Kod naše pacijentkinje bio prisutan umor koji bi se mogao dovesti u vezu sa pojavom još dva definisana simptoma: anemija i poremaćajem spavanja. Racionalni pristup lečenju treba da ima tri aspekta: prvi koji se bavi osnovnim reverzibilnim faktorima, drugi koji koristi nefarmakološki i na kraju farmakološki pristup [19]. Nefarmakološki pristup podrazumeva: planirannje potrošnje energije tj. odmereno planiranje dnevnih aktivnosti ili davanje prioriteta aktivnostima koje treba preduzeti u vreme prisutnog zamora i maksimalne energije. Strategije obnavljanja energije uključuju osiguravanje odgovarajućeg odmora, ishrane, smanjenje stresa tehnikama poput meditacije ili opuštanja. Fizičke vežbe su prihvaćene kao koristan pristup u mnogim kliničkim ispitivanjima [20]. Nivo fizičke vežbe treba prilagoditi osnovnom stanju bolesti, mogućnostima i opštem blagostanju pacijenta. Pacijenti sa umorom koji su anemični sa hemoglobinom $<8 \mathrm{~g} / \mathrm{dl}$ mogu se zbrinjavati sa transfuzijom krvi, čiji je cilj održavanje nivoa hemoglobina od 10 do 12 g/dl [21]. Primena steroida (dexametazon) nije korisna za dugotrajnu kontrolu umora, ali njihova primena može pomoći u kratkotrajnom rešavanju umora za pacijenta koji želi da ima optimalnu budnost za važnu priliku ili porodični događaj.

Smetnje sa snom kod pacijenata obolelih od raka, često su manifestacija prisutne anksioznosti koja se javlja u vidu straha i strepnje, osećaja knedle u grlu, stezanja u grudima ili stomaku, mučnine, teškoće u koncentraciji, poteškoća u prihvatanju ili opozivu informacija. Promenjena percepcija viđenja okruženja, postupaka i ishoda tretmana, mogu izazvati poremaćaj u spavanju. Pažljiva permanantna procena spavanja i primena odgovarajućih nefarmakoloških i farmakoloških strategija nege kod pacijenta može u mnogome poboljšati ili redukovati mnoge simptome poput umora [22].

Onkološki kliničari i sestre specijalisti za onkološku negu, kao i sestre koje rade u timu za palijativno zbrinjavanje mogu u velikoj meri doprineti ublažavanju i kontroli problema i simptoma poput bola, anksioznosti, umora, poremaćaja spavanja, deficita u samozbrinjavanju, prevenciji komplikacija, kao i edukaciji pacijenta i porodice kako da se što uspešnije nose sa problemima. Adekvatna briga za emocionalne i informativne potrebe pacijenata i njihovih porodica tokom lečenja i dugotrajnog zbrinjavanja 
uz adekvatnu interprofesionalnu saradnju zdravstvenih profesionalaca u sistemu zdravstvene zaštite predstavlja imperative $\mathrm{u}$ zbrinjavanju populacije obolelih od malignih bolesti naročito u zemljama sa ograničenim resursima.

\section{ZAKLJUČAK}

Nakon utvrđenih potreba za zdravstvenom negom, postavljanja dijagnoza nege, kolaborativnih problema, ciljeva nege, sastavljenog plana nege i evaluacije ciljeva utvrđeno je da se značaj sestrinskih intervencija ogleda u sprovođenju aktivnosti koje poboljšavaju kvalitet življenja u odmaklim fazama bolesti i ublažavanju simptoma bolesti. Sestrinske aktivnosti koje se sprovode u cilju otklanjanja i u proceni bola, procena stanja svesti, praćenje pojave mučnine, povraćanja, umora, značajne su radi uspostavljanja dobre kontrole simptoma bolesti ili posledice lečenja. Medicinska sestra pružajući negu gradi poverenje izmedju pacijenta i njegove porodice, čime i omogućava rešavanja drugih problema. Medicinske sestre kao članovi interprofesionalnih timova, shodno svojim profesionalnim kompetencijama učestvuju i bave se mnogim problemima obolelih od raka dojke dajući značajan doprinos njihovom humanom zbrinjavanju $\mathrm{u}$ sistemu zdravstvene zaštite.

\section{LITERATURA}

1. Milosavljević Kostić M. Interna medicina. Beograd: Visoka zdravstvena škola strukovnih studija, 2017.

2. Mariotto AB, Etzioni R, Hurlbert M, Penberthy L, Mayer M. Estimation of the Number of Women Living with Metastatic Breast Cancer in the United States. Cancer Epidemiol Biomarkers Prev. 2017;26(6):809-15.

3. Thrift-Perry M, Cabanes A, Cardoso F, Hunt KM, Cruz TA, Faircloth K. Global analysis of metastatic breast cancer policy gaps and advocacy efforts across the patient journey. Breast. 2018;41:93-106.

4. Bošković S. Zdravstvena nega u onkologiji. Beograd: Visoka zdravstvena škola strukovnih studija, 2012; str. 166.

5. Swain SM, Baselga J, Miles D, et al. Incidence of central nervous system metastases in patients with HER2-positive metastatic breast cancer treated with pertuzumab, trastuzumab, and docetaxel: results from the randomized phase III study CLEOPATRA. Ann Oncol. 2014;25(6):1116-21.

6. Kalinsky K, Sammons S, Shah B. Defining Value in the Treatment of Brain Metastasis in Metastatic Breast Cancer. AJMC INSIGHTS. 2020.

7. Petrujkić D. K. Mogućnosti kvantitativne analize slike dobijene magnetnom rezonancom u razlikovanju glioblastoma od solitarnemetastaze mozga (doktorska disertacija). Beograd: Medicinski fakultet, 2020.

8. NCCN. Central nervous system cancers. Clinical Practice Guidelines in Oncology version, 2020. https://www.nccn. org/professionals/physician_gls/pdf/cns.pdf

9. Brunault P, Champagne AL, Huguet G. Major depressive disorder, personality disorders, and coping strategies are independent risk factors for lower quality of life in non-metastatic breast cancer patients. Psycho-Oncology. 2016;25:513-20.

10. Sejpal SV, Bhate A, Small W. Palliative radiation therapy in the management of brain metastases, spinal cord compression, and bone metastases. Semin Intervent Radiol. 200724(4):363-74

11. Ahmed N, Ahmedzai SH, Collins K. Holistic assessment of supportive and palliative care needs: the evidence for routine systematic questioning. BMJ Support Palliat Care. 2014;4(3):238-46.

12. Hallenbeck J, Arnold R. A request for nondisclosure: don't tell mother. J Clin Oncol. 2007;25(31):5030-34.

13. Raskin W, Harle I, Hopman WM, Booth CM. Prognosis, Treatment Benefit and Goals of Care: What do Oncologists Discuss with Patients who have Incurable Cancer?. Clin Oncol (R Coll Radiol) 2016;28(3):209-14.

14. Cleeland CS, Gonin R, Hatfield AK, et al. Pain and its treatment in outpatients with metastatic cancer. N Engl J Med. 1994;330:592-96.

15. BT Li, Wong MH, Pavlakis N. Treatment and prevention of bone metastases from breast cancer: a comprehensive review of evidence for clinical practice. J Clin Med. 2014;3(1):1-24.

16. Singh PC, Patel DV, Chang VT. Metastatic acetabular fractures: evaluation and approach to management. J Pain Symptom Manage. 2006;32(5):502-7.

17. Mercadante S, Fulfaro F. Management of painful bone metastases. Curr Opin Oncol. 2007;19(4):308-14.

18. Ripamonti CL, Santini D, Maranzano E, Berti M, Roila F, ESMO Guidelines Working Group Management of cancer pain: ESMO clinical practice guidelines. Ann Oncol. 2012;23:vii139-vii154.

19. Mohandas H, Jaganathan SK, Mani MP, Ayyar M, Rohini Thevi GV. Cancer-related fatigue treatment: An overview. J Cancer Res Ther. 2017;13(6):916-29.

20. Juvet LK, Thune I, Elvsaas IKØ, et al. The effect of exercise on fatigue and physical functioning in breast cancer patients during and after treatment and at 6 months follow-up: A meta-analysis. Breast. 2017;33:166-77.

21. Carson JL, Guyatt G, Heddle NM, et al. Clinical practice guidelines from the AABB: Red blood cell transfusion thresholds and storage. JAMA 2016;316(19):2025-35.

22. Roth AJ, Massie MJ. Anxiety and its management in advanced cancer. Curr Opin Support Palliat Care. 2007;1(1):50-6. 